\title{
36. 壁最上部から照明する高効率型間接照明方式の開発
}

\author{
藤田 茂明 安岡 悦章 中尾 晋也 \\ (大光電機株式会社)
}

\section{1.はじめに}

オフィスの重要な照明要件として、直射·反射グレアの防止、光幕反射の 防止、机上面輝度分布の一様性 ${ }^{1}$ があり、この遵守の為、間接照明方式の 採用が期待される。しかし、従来の間接照明方式は、照明台数が増加すると いう省エネ上の問題があり、この問題を解决する為、天井吊方式の高効率 型間接昭明(以下「天井吊方式にと呼ぶ)を過去に開発した ${ }^{2)}$ ，3)。

しかし、この間接照明方式は、器具を天井から $0.8 \mathrm{~m}$ 吊り下げる為、通常 の天井高(例、 $2.7 \mathrm{~m}$ ) では、器具による圧迫感等の問題があった。

今般、これらの問題を解决する為、壁最上部から照明する高効率型間接 照明方式(以下壁取付方式と呼ぶ)を開発したので報告する。

\section{2. 開発の概要}

壁取付方式の概念を図 1 に、今回使用した照明器具外観を図 2 に、配光特 性を図 3 に示す。なお、今回の照明器具は、反射板・ルーバー共、高反射率ア ルミ板（反射特性：鏡面反射十拡散反射、全反射率 $94 \%$ ) とし、蛍光管 T5 管 $54 \mathrm{~W}$ $\times 1(5000 \mathrm{~lm})$ 、器具効率93.7\%のもの(開発品)を使用した。

\section{3. 結果など}

小部屋 $(4 \times 4 \mathrm{~m}$ 、天井高 $2.7 \mathrm{~m})$ の場合、壁取付方式による室内光環境を図 4 に、机上面照度 $(\mathrm{H}=700)$ 実測值を図 5 に示す。

机上面平均照度は、天井吊方式に比較して $93.2 \%$ $\%$ 、また、直接照明方 式(天井直付型器具、反射板: 白、ルーバー:白) ${ }^{2}, 3$ ) に比較して $94.0 \%$ なお、直射・反射グレアがなく、光幕反射が極めて少ない事を確認した。

また、大部屋 $(14 \times 15.75 \mathrm{~m}$ 以上、天井高 $2.7 \mathrm{~m})$ の場合、壁取付方式による照 明所要台数は、直接照明方式(同上)に比較して 9. 4 13.2\%(計算值)削减可 能と期待された $\left.{ }^{2}, 3\right)$ 。

さらに、直射グレア・反射グレア・光幕反射等がない質の高い照明において、 設計照度を500 1x (注、屋内照明基淮 オフィス設計值 $7501 x$ ) に設定できる4 と考えられる為、大部屋(同上)の場合、壁取付方式による照明所要台数は、直 接照明方式(同上)に比較して、40 42\%(計算値)削減可能と期待された ${ }^{2,3}$ 。

\section{4. まとめ}

壁取付方式による室内環境は、以下に示寸特徵があり、同方式は、明視性 と省エネ性を両立させた高効率(高照明率)な間接照明方式と考えられる。

(1)天井吊方式のような照明器具による圧迫感がなく、また、ハングレアで光 幕反射が極めて少なく、さらに、机上面照度が一様な、さらにまた、天井 がスッキリした、空間が形成される。

(2)小部屋(同上)の場合、机上面照度は、直接照明方式(同上)に比較し、ほぼ同 等(実測値)であり、大部屋(同上)の場合、照明所要台数は、直接照明方式 (同上)に比較し、約 $1 \sim 4$ 割(計算値) 削减可能と期待される。

文献:1) タスク照明の心理・生理的影琝に関するフィールド実験 藤田他 日本建筑学会 大会 学術講演梗概集 p. 201-202 1990

2) 高反射率アルミ反射板を用いた天井吊間接照明の検討 藤田他 電気設備学会 全国大会講演論文集 p. $187-1902001$

3) 間接照明による明視環境改善と省エネルギー化の検討 藤田他 平成 14 年 電気 関倸学会関西支部連合大会 講演論文集 p. S34 2002

4）タスク・アンビエント照明の快適性とエネルギー評価（その２）長時間の執務にお ける照度の影響 藤田他 日本建筑学会大会学術講演梗概集 p. $365-3661998$ Development of New Hi-Efficiency Indirect Lighting System with Luminaire attached on Top Wall. / Shigeaki Fujita, Yoshiaki Yasuoka, Shinya Nakao

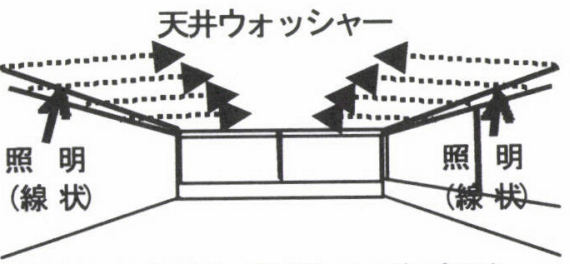

図 1. 壁取付方式間接照明(概念図)

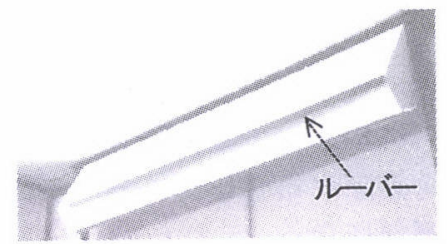

図 2. 照明器具外観 $\left(1220^{L} \times 220^{\mathrm{H}} \times 160^{\mathrm{D}}\right)$

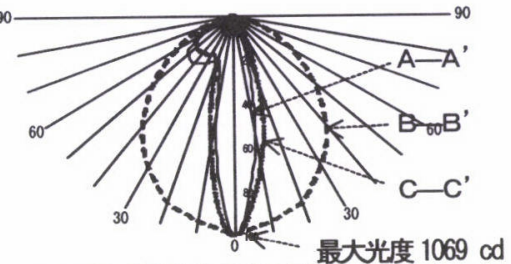

図 3. 照明器具配光特性

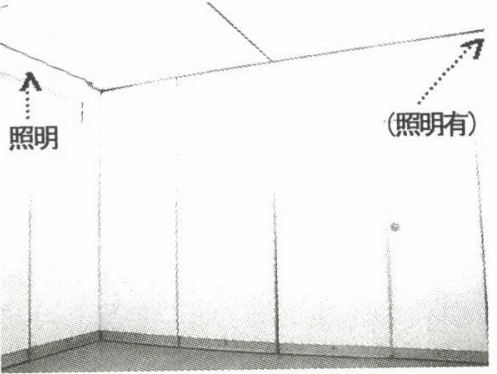

図 4. 室内光環境(直射·反射グレア等無)

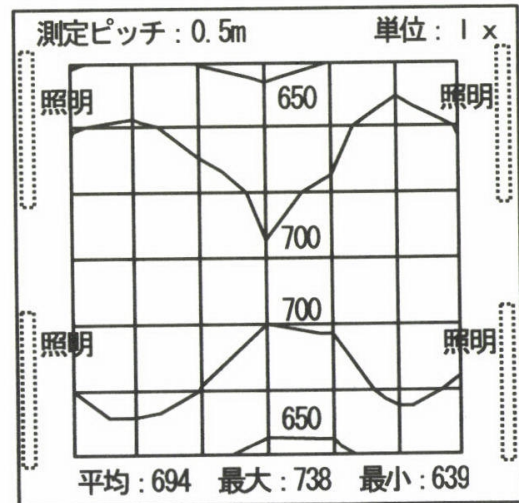

図 5. 机上面照度分布 (室 : $4 \times 4 \times 2.7^{\mathrm{H}} \mathrm{m}$ ) （反射率 天井: 0.79 壁: 0.835 床: 0.25 ) 